\title{
KEPUASAN MASYARAKAT TERHADAP KUALITAS PELAYANAN E-KTP DI DINAS KEPENDUDUKAN DAN PENCATATAN SIPIL KABUPATEN SRAGEN
}

\section{PUBLIC SATISFACTION TOWARDS QUALITY E-KTP SERVICE IN THE DEPARTMENT OF POPULATION AND CIVIL REGISTRATION SRAGEN REGENCY}

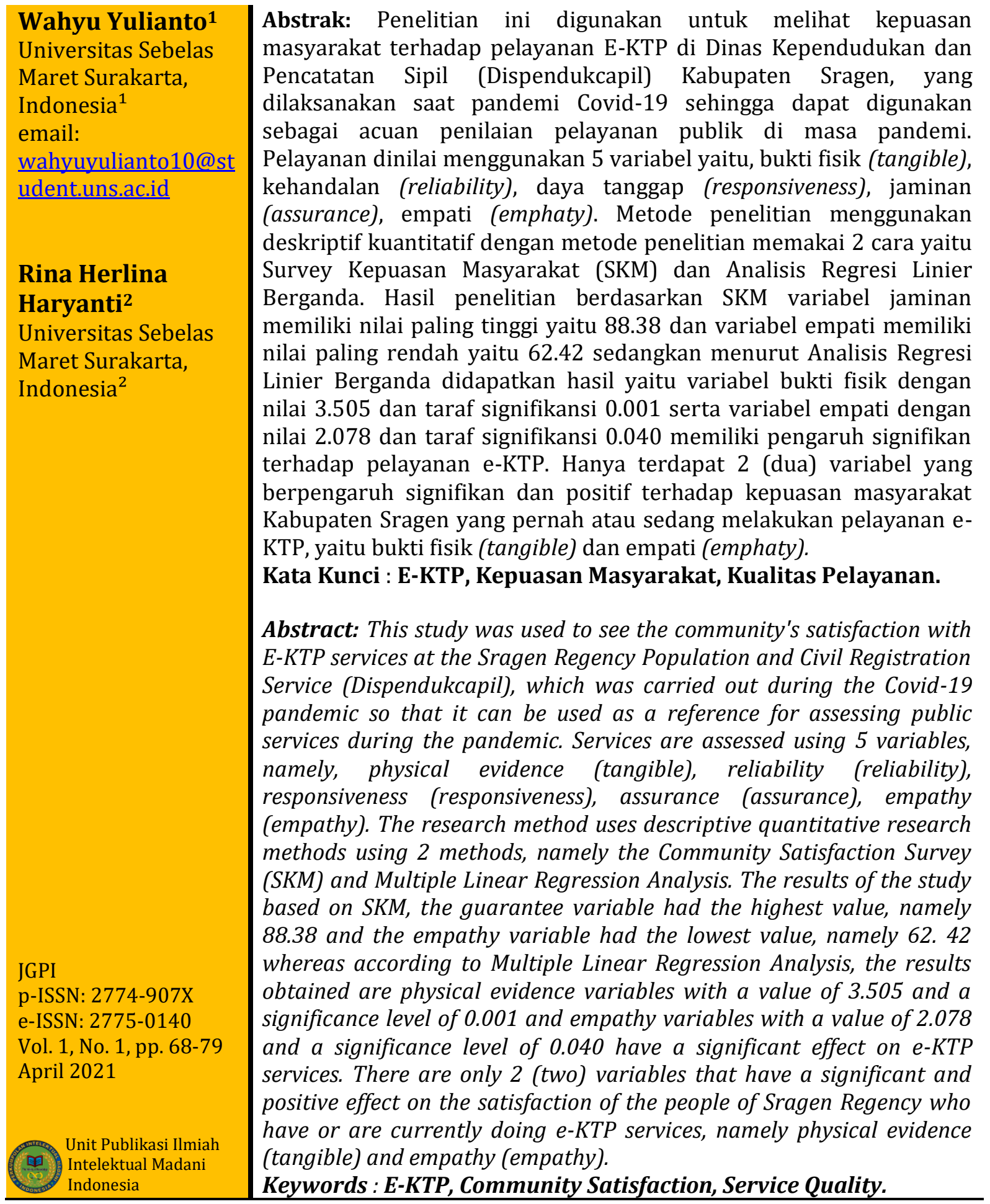




\section{PENDAHULUAN}

Penduduk adalah orang-orang yang tinggal di sebuah wilayah tertentu (negara) dalam jangka waktu yang lama, hal tersebut dijelaskan dalam UndangUndang Nomor 52 Tahun 2009 bahwa dalam pembangunan nasional harus mencakup semua aspek kehidupan termasuk perkembangan kependudukan di Indonesia. Perkembangan Kependudukan di Indonesia tidak hanya berisi tentang kuatitas (data) seperti struktur umur, kelahiran dan kematian tetapi juga meliputi tentang masalah pendidikan, kesehatan dan kesejahteraan termasuk persebaran penduduk atau biasa disebut kualitas penduduk. Menurut Undang-Undang Nomor 24 Tahun 2013 tentang Administrasi Kependudukan, arsip atau dokumen ini berisi data kependudukan yang dialami oleh penduduk baik di wilayah atau di luar wilayah Negara Kesatuan Republik Indonesia (NKRI), salah satu dokumen identitas hukum yang dibutuhkan oleh penduduk di Indonesia adalah Kartu Tanda Penduduk (KTP), (ANRI, 2012).

Kartu Tanda Penduduk (KTP) saat ini juga telah disempurnakan dengan program berbasis elektronik atau elektronik KTP (e-KTP) dengan tujuan agar database kependudukan terintegrasi secara nasional sesuai dengan Peraturan presiden (Perpres) nomor 35 Tahun 2010. Setiap e-KTP pasti memiliki Nomor Induk Kependudukan (NIK) yang mempunyai sistem keamanan single identity number sebagai alat untuk verifikasi dan validasi data kependudukan, dilihat dari teknologi informasi dan administrasi (Panjaitan \& Yuniati, 2016). Tujuan dari penerapan tersebut adalah mencegah adanya KTP yang ganda serta digunakan dalam penerbitan paspor, Surat Izin Mengemudi (SIM), Nomor Pokok Wajib Pajak (NPWP), Asuransi, sertifikat-sertifikat serta dalam lingkup partisipasi politik seorang warga negara dapat menggunakan hak pilih jika memiliki eKTP, jika seseorang belum memiliki e-KTP tentu warga negara tidak dapat menggunakan hak pilih mereka karena secara otomatis NIK belum terintegrasi dan terdaftar secara nasional kemudian orang tidak akan bisa mengurus pelayanan seperti BPJS Kesehatan maupun pelayanan yang lain jika tidak memiliki e-KTP (Sutriadi, Dahlan, \& Hasim, 2018).

Fungsi e-KTP berdasarkan pasal 6 Perpres No 26 Tahun 2009 tentang Penerapan KTP berbasis Nomor Induk Kependudukan Secara Nasional Jo Perpres No 35 Tahun 2010 tentang perubahan atas Perpres No 26 Tahun 2009 antara lain, (1) Sebagai identitas diri, karena memuat kode keamanan dan rekaman elektronik sebagai alat verifikasi dan validasi data (2) Ruang Lingkup adalah Nasional, sehingga tidak ada lagi pembuatan KTP berbasis lokal dan konvensional (3) Mencegah adanya pemalsuan KTP 
dan ganda, karena sudah berbasis elektronik sehingga data dari penduduk sangat akurat. Dikutip dari kompas.com, menurut Direktur-Jenderal Kependudukan dan Pencatatan Sipil (Dukcapil)-Kementerian Dalam Negeri Zudan-Arif-Fakrulloh jumlah itu setara 94,98 persen, dan masih terdapat sekitar 9.300.584 jiwa di Indonesia yang belum-melakukanperekaman-data e-KTP sampai saat ini, yang-berarti masih-ada sekitar 5,12 \% penduduk Indonesia belum melakukan perekaman data e-KTP. Dalam proses pelaksanaan-program e-KTP di Indonesia terdapat banyak kendala yang mempengaruhi dari perekaman data penduduk, kendala dan permasalahan yang terjadi berdasarkan penelitian dari (Febriharini, 2016) antara lain, (1) Sarana dan prasarana, kondisi alat perekaman data penduduk mayoritas sudah lama dan tua, berumur sekitar 8 tahun atau sejak tahun 2011, (2) Ketersediaan dari blangko KTP elektronik, kendala ini masih dialami oleh banyak penduduk, Dinas Kependudukan dan Pencatatan Sipil (Dispendukcapil) kekurangan blangko sehingga penduduk hanya diberikan surat keterangan, (3) Antrean dalam pelayanan, hampir seluruh daerah sampai saat ini mengalami masalah antrean yang mengular panjang bahkan sebelum dibuka dari bagian pelayanan, (4) Jaringan Internet, tidak semua daerah di Indonesia mempunyai jaringan internet yang kuat dan memadai untuk proses perekaman data, validasi dan verifikasi data penduduk, (5) Masih terdapat praktik percaloan dan pengutan liar, berdasarkan data dari Ombudsman Republik Indonesia (ORI) bentuk percaloan dan pungutan itu biasanya dilakukan dengan memanfaatkan situasi di lapangan, dengan kondisi pelayanan yang antri panjang, para calo memanfaatkan untuk mengambil keuntungan dari masyarakat yang tidak mau repot dan antri dalam mengikuti prosedur pelayanan.

Kendala dan masalah yang ada memang membuat tingkat kepuasan penduduk di Indonesia sedikit turun, mengingat program e-KTP ini bersifat nasional dan seharusnya dapat membuat masyarakat menjadi lebih mudah dalam segala sesuatu dan database yang direkam aman karena langsung disimpan di pusat. Tetapi program e-KTP ini terus berjalan karena telah diatur dalam UU dan setiap Provinsi serta Kabupaten/Kota telah melaksanakannya, salah satu Provinsi yang terus mempercepat perekaman data e-KTP adalah Jawa Tengah, (Arianto, 2019).

Contoh Kabupaten/Kota di Indonesia, khususnya di Jawa Tengah yang juga mempunyai masalah dan kendala dalam pelayanan Dispendukcapil adalah Kabupaten Sragen. Dikutip dari http://www.sragen.go.id/ Sragen adalah Kabupaten yang berada di Provinsi Jawa Tengah dengan luas wilayah sekitar 941,55 km2, terbagi menjadi 20 
Kecamatan, 12 Kelurahan dan 196 Desa serta mempunyai jumlah penduduk mencapai 986.708 jiwa berdasarkan penghitungan terakhir tahun 2018. Dispendukcapil Sragen walaupun mempunyai masalah dalam pelayanan dokumen identitas hukum tetapi juga mempunyai inovasi dalam pelayanan dan kepengurusan dokumen tersebut, inovasi yang dilakukan antara lain (Humas Pemkab Sragen , 2019), yaitu (1) SEMEDI (Sedino Mesti Dadi) merupakan program andalan Dispendukcapil Sragen sejak tahun 2015 yaitu pengurusan akta kelahiran dan dokumen kependudukan sehari jadi, dan sejak tahun 2017 menjadi inovasi pelayanan publik berskala nasional, (2) Anjungan Tempat Mencetak (ATM) yang ditunjukkan untuk Kartu Identitas Anak (KIA), digunakan untuk mempermudah masyarakat karena tidak perlu antre lagi karena cukup dengan mendaftar via aplikasi online, (3) LAPUR KAKAK (Layanan Purna KTP dan KK), mempunyai tujuan memberikan kemudahan bagi Aparatur Sipil Negara (ASN) yang sudah purna tugas untuk mengurus e-KTP dan KK, (4) Tanda Tangan Elektronik (TTE KK \& Akta), (5) PECEL PINDANG (Percepatan Layanan Pindah Datang), (6) BARATA (Bayi Lahir Berakta).

Inovasi yang dilakukan Dispendukcapil Kabupaten Sragen tersebut sebenarnya juga menunjukkan bahwa daerah mempunyai cara atau kreativitas masing-masing di dalam melakukan pelayanan terhadap masalah dokumen identitas hukum penduduk di wilayah tersebut, dengan adanya inovasi yang dilakukan membuat pelayanan yang ada menjadi lebih mudah dan efisien tentunya. Tetapi seperti masalah yang terjadi dalam lingkup nasional, masalah yang ada di daerah juga tidak dapat untuk disepelekan, khususnya dalam pelayanan di Dispendukcapil Kabupaten Sragen, masalah atau kendala yang muncul beberapa kali menjadi pusat pemberitaan di media massa, baik media cetak, elektronik maupun internet, baik itu lingkup media daerah bahkan sampai nasional, masalah tersebut antara lain mengenai kekurangan blangko e-KTP sehingga Dispendukcapil Kabupaten Sragen harus meminjam ke Kabupaten lain, pelayanan yang kadang masih terpusat di kota, keterbatasan alat, masih munculnya praktek percaloan dan yang sering terjadi adalah dokumen e-KTP yang tidak pernah sampai ke pemiliknya (Tarmy, 2019). Dinas Kependudukan dan Pencatatan Sipil (Dispendukcapil) Kabupaten Sragen memang mengakui bahwa pelayanan yang telah dilakukan belum sempurna, dikutip dari joglosemarnews.com, tetapi Dispendukcapil tetap berusaha untuk maksimal dalam pelayanan karena data pemilik identitas hukum di wilayah Kabupaten Sragen belum semuanya mencapai 100\% atau mencapai target (Wardoyo, 2019). 
Di bawah ini adalah data yang didapat dari Dinas Kependudukan dan Pencatatan Sipil (Dispendukcapil) Kabupaten Sragen mengenai wajib KTP dan kepemilikan KTP di Kabupaten Sragen.

Tabel 1

\section{Data Wajib Memiliki KTP di Kabupaten Sragen}

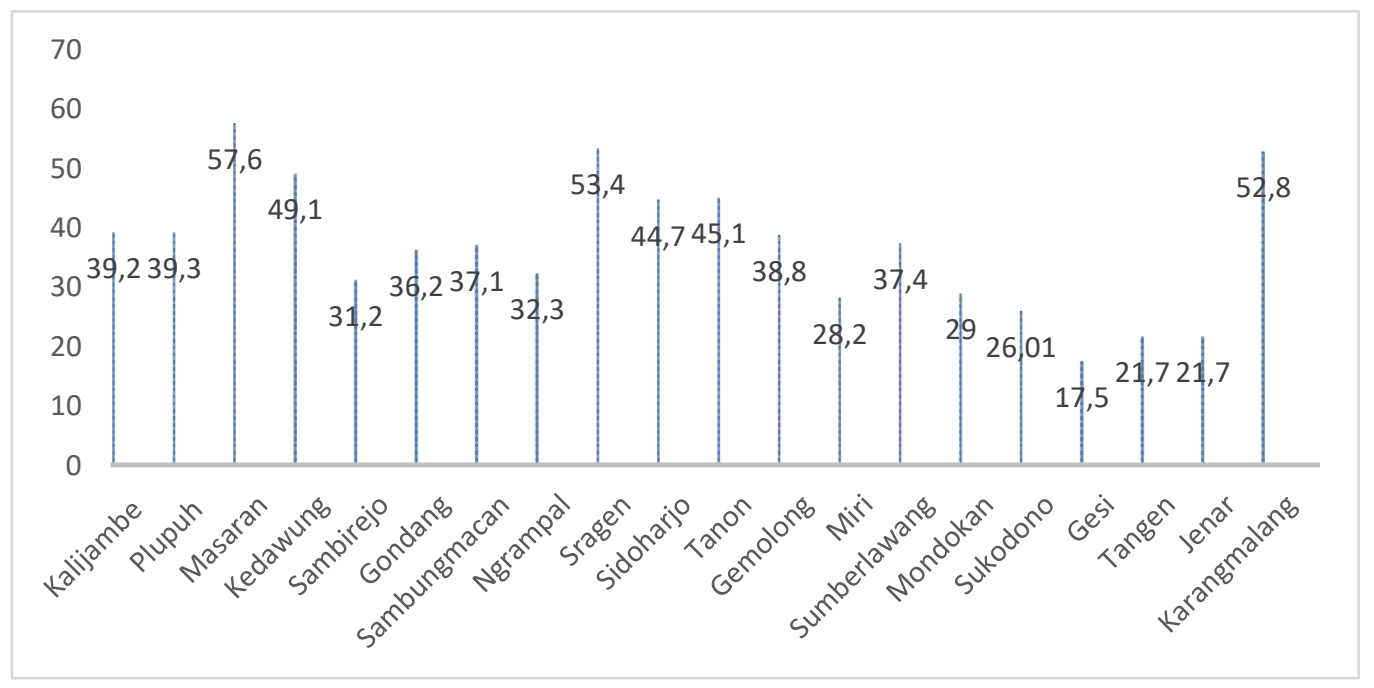

Sumber : Buku Kependudukan Dispendukcapil Kab. Sragen tahun 2019

Tabel 2

Data Kepemilikan KTP di Kabupaten Sragen

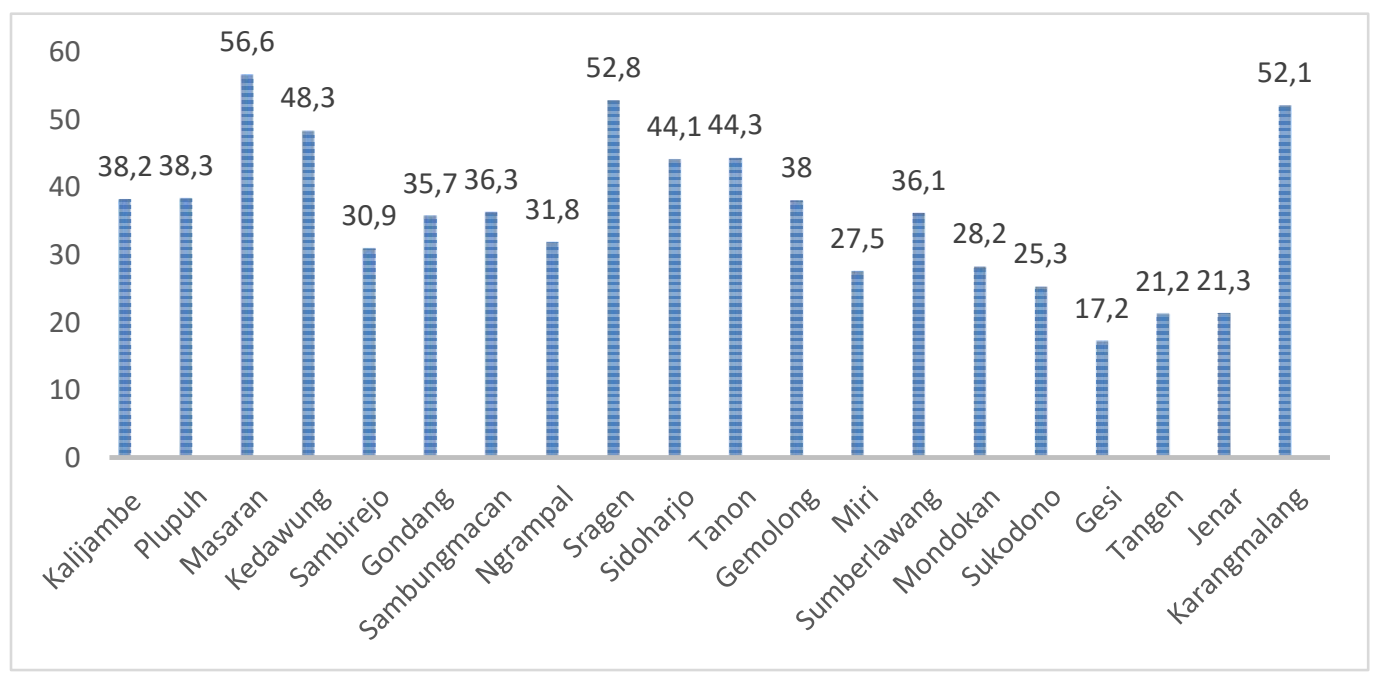

Sumber : Buku Kependudukan Dispendukcapil Kab. Sragen tahun 2019

Data dari Dispendukcapil Kabupaten Sragen pada tahun 2019, jumlah penduduk di Kabupaten Sragen adalah 986.708 jiwa, dengan penduduk yang wajib memiliki KTP adalah 739.430 jiwa dan dari jumlah tersebut sekitar 725.008 jiwa sudah melakukan perekaman data dan memiliki KTP (data kependudukan Sragen, 2018). Kualitas pelayanan publik menjadi bukti dalam pengukuran kepuasan masyarakat, berdasarkan 
teori SERVQUAL yang dikemukakan dalam oleh (Zeithaml et al, 1990 dalam Sigit \& Oktafani, 2014) kualitas pelayanan publik diukur dengan menggunakan dimensi pelayanan publik yaitu (1) Bukti Fisik (Tangible) (2) Kehandalan (Reliability) (3) Daya Tanggap (Responsiveness) (4) Jaminan (Assurance) dan (5) Empati (Emphaty). Berdasarkan data diatas terlihat masih ada masalah dalam pelayanan e-KTP di Kabupaten Sragen, sehingga penelitian ini akan mengambil masalah apakah kualitas pelayanan e-KTP mempunyai pengaruh signifikan terhadap kepuasan masyarakat di Dispendukcapil Kabupaten Sragen dengan menggunakan analisis regresi linier berganda.

\section{METODE}

Penelitian ini dilakukan di lingkungan Dinas Kependudukan dan Pencatatan Sipil (Dispendukcapil) Kabupaten Sragen, sumber data yang diperoleh berasal dari kuisioner yang dibagikan ke penduduk yang sedang berada di bagian pelayanan e-KTP, sedangkan sampel yang digunakan berjumlah 100 responden. Hasil kuisioner dihitung dengan menggunakan rumus Survey Kepuasan Masyarakat (SKM) dan analisis regresi linier berganda. Uji validitas penelitian ini dilakukan di luar lokasi penelitian, dalam hal ini uji validitas dilakukan terhadap penduduk yang pernah melakukan pelayanan e-KTP di Kota Surakarta, adapun sampel yang didapatkan berjumlah 31 responden. Metode untuk menganalisis data dalam penelitian ini adalah deskriptif kuantitatif.

Variabel bebas yang terdapat dalam penelitian ini antara lain (1) Bukti Fisik (Tangible) (2) Kehandalan (Reliability) (3) Daya Tanggap (Responsiveness) (4) Jaminan (Assurance) dan (5) Empati (Emphaty), sedangkan variabel terikat yang terdapat dalam penelitian ini adalah kualitas pelayanan e-KTP di Dinas Kependudukan dan Pencatatan Sipil (Dispendukcapil) Kabupaten Sragen (Sugiyono, 2017).

\section{HASIL DAN DISKUSI}

Hasil dari penghitungan penelitian ini diambil dengan 2 (dua) cara yaitu, Survey Kepuasan Masyarakat (SKM) dan Analisis Regresi Linier Berganda. Penggunaan SKM mempunyai tujuan untuk melihat nilai kepuasan masyarakat terhadap pelayanan e-KTP di Dinas Kependudukan dan Pencatatan Sipil (Dispendukcapil) Kabupaten Sragen, berdasarkan penghitungan yang telah dilakukan variabel jaminan (assurance) memiliki nilai paling besar yaitu 88.38 serta memiliki mutu pelayanan sangat baik (A) sedangkan variabel empati (emphaty) memiliki nilai paling kecil yaitu 72.42 serta memiliki mutu 
pelayanan kurang baik (C). Penghitungan tersebut dilaksanakan dengan menggunakan 100 responden, dimana 50 orang didapatkan saat berada di Dispendukcapil Kabupaten Sragen sedangkan 50 orang sisanya didapatkan dengan bantuan google form, hal tersebut dikarenakan penelitian berlangsung saat pandemi Covid-19 sehingga pelayanan Dispendukcapil Kabupaten Sragen menjadi dibatasi, kurang maksimal dan pelayanan sempat buka tutup beberapa kali. Selain itu, pelayanan perekaman data baru untuk eKTP pemula juga sempat berhenti total untuk meminimalisir penyebaran virus Covid-19, jadi untuk sementara menggunakan Surat Keterangan (SUKET) sebagai identitas hukum.

Tabel 3

Deskripsi Hasil Penelitian

\begin{tabular}{c|l|l|l}
\hline Hipotesis & Deskripsi & Variabel & Hasil \\
\hline $\mathrm{H}_{1}$ & $\begin{array}{l}\text { Bukti fisik berpengaruh signifikan terhadap } \\
\text { kepuasan masyarakat pengguna layanan e- } \\
\text { KTP di Kabupaten Sragen }\end{array}$ & TAN $\rightarrow$ KEP & Berpengaruh \\
\hline $\mathrm{H}_{2}$ & $\begin{array}{l}\text { Kehandalan berpengaruh signifikan } \\
\text { terhadap kepuasan masyarakat pengguna } \\
\text { layanan e-KTP di Kabupaten Sragen }\end{array}$ & REL $\rightarrow$ KEP & $\begin{array}{l}\text { Tidak } \\
\text { Berpengaruh }\end{array}$ \\
\hline $\mathrm{H}_{3}$ & $\begin{array}{l}\text { Daya Tanggap berpengaruh signifikan } \\
\text { terhadap kepuasan masyarakat pengguna } \\
\text { layanan e-KTP di Kabupaten Sragen }\end{array}$ & RES $\rightarrow$ KEP & $\begin{array}{l}\text { Tidak } \\
\text { Berpengaruh }\end{array}$ \\
\hline $\mathrm{H}_{4}$ & $\begin{array}{l}\text { Jaminan berpengaruh signifikan terhadap } \\
\text { kepuasan masyarakat pengguna layanan e- } \\
\text { KTP di Kabupaten Sragen }\end{array}$ & ASS $\rightarrow$ KEP & $\begin{array}{l}\text { Tidak } \\
\text { Berpengaruh }\end{array}$ \\
\hline $\mathrm{H}_{5}$ & $\begin{array}{l}\text { Empati berpengaruh signifikan terhadap } \\
\text { kepuasan masyarakat pengguna layanan e- } \\
\text { KTP di Kabupaten Sragen }\end{array}$ & EMP $\rightarrow$ KEP & Berpengaruh \\
\hline
\end{tabular}

Sumber : Data Primer yang Diolah, 2020

\section{Variabel Bukti Fisik $\left(\mathrm{H}_{1}\right)$ Berpengaruh Signifikan dan Positif Terhadap Kepuasan Masyarakat}

Berdasarkan analisis penelitian diatas, telah diambil kesimpulan yaitu $\mathrm{H}_{1}$ berpengaruh signifikan dan positif terhadap kepuasan masyarakat Kabupaten Sragen yang melakukan pelayanan e-KTP. Hal tersebut didukung dengan hasil uji t (uji parsial) variabel bukti fisik yang memiliki nilai thitung sebesar 3.505 dan nilai signifikansi 0.001, perbandingan nilai $t_{\text {hitung }}$ dengan nilai $t_{\text {tabel, }}$ sehingga ditemukan hasil bahwa nilai $t_{\text {hitung }}$ variabel bukti fisik memiliki nilai 3.505, angka tersebut lebih besar dari nilai $t_{\text {tabel }}$ yaitu 1.986, kemudian untuk perbandingan nilai signifikansi dengan nilai taraf signifikansi, yaitu 0.05 , ditemukan hasil bahwa nilai signifikansi variabel bukti fisik sebesar 0.001 lebih kecil dari 0.05 . 


\section{Variabel Kehandalan $\left(\mathrm{H}_{2}\right)$ Tidak Berpengaruh Signifikan Terhadap Kepuasan Masyarakat}

Berdasarkan analisis penelitian diatas, telah diambil kesimpulan yaitu $\mathrm{H}_{2}$ tidak berpengaruh signifikan terhadap kepuasan masyarakat Kabupaten Sragen yang melakukan pelayanan e-KTP. Hal tersebut didukung dengan hasil uji t (uji parsial) variabel kehandalan yang memiliki nilai thitung sebesar 0.898 dan nilai signifikansi 0.373 , perbandingan nilai thitung dengan nilai $t_{\text {tabel, }}$ sehingga ditemukan hasil bahwa nilai thitung variabel bukti fisik memiliki nilai 0.898, angka tersebut lebih kecil daripada nilai $t_{\text {tabel }}$ yaitu 1.986, kemudian untuk perbandingan nilai signifikansi dengan nilai taraf signifikansi, yaitu 0.05, ditemukan hasil bahwa nilai signifikansi variabel bukti fisik sebesar 0.373 lebih besar dari 0.05 .

\section{Variabel Daya Tanggap $\left(\mathrm{H}_{3}\right)$ Tidak Berpengaruh Signifikan Terhadap Kepuasan Masyarakat}

Berdasarkan analisis penelitian diatas, telah diambil kesimpulan yaitu $\mathrm{H}_{3}$ tidak berpengaruh signifikan terhadap kepuasan masyarakat Kabupaten Sragen yang melakukan pelayanan e-KTP. Hal tersebut didukung dengan hasil uji t (uji parsial) variabel daya tanggap yang memiliki nilai thitung sebesar 1.707 dan nilai signifikansi 0.091, perbandingan nilai thitung dengan nilai tabel, sehingga ditemukan hasil bahwa nilai

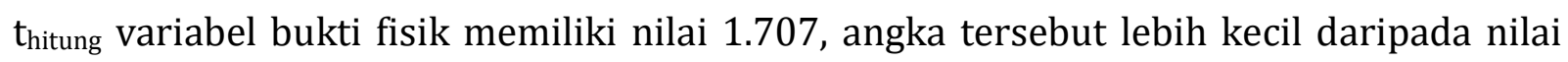
$t_{\text {tabel }}$ yaitu 1.986, kemudian untuk perbandingan nilai signifikansi dengan nilai taraf signifikansi, yaitu 0.05, ditemukan hasil bahwa nilai signifikansi variabel bukti fisik sebesar 0.091 lebih besar dari 0.05 .

\section{Variabel Jaminan $\left(\mathrm{H}_{4}\right)$ Tidak Berpengaruh Signifikan Terhadap Kepuasan Masyarakat}

Berdasarkan analisis penelitian diatas, telah diambil kesimpulan yaitu $\mathrm{H}_{4}$ tidak berpengaruh signifikan terhadap kepuasan masyarakat Kabupaten Sragen yang melakukan pelayanan e-KTP. Hal tersebut didukung dengan hasil uji t (uji parsial) variabel jaminan yang memiliki nilai $t_{\text {hitung }}$ sebesar -0.573 dan nilai signifikansi 0.568 , perbandingan nilai $t_{\text {hitung }}$ dengan nilai $t_{\text {tabel, }}$ sehingga ditemukan hasil bahwa nilai $t_{h i t u n g}$ variabel bukti fisik memiliki nilai -0.573, angka tersebut lebih kecil daripada nilai tabel yaitu 1.986, kemudian untuk perbandingan nilai signifikansi dengan nilai taraf 
signifikansi, yaitu 0.05, ditemukan hasil bahwa nilai signifikansi variabel bukti fisik sebesar 0.568 lebih besar dari 0.05 .

\section{Variabel Empati $\left(\mathrm{H}_{5}\right)$ Berpengaruh Signifikan dan Positif Terhadap Kepuasan Masyarakat}

Berdasarkan analisis penelitian diatas, telah diambil kesimpulan yaitu $\mathrm{H}_{5}$ berpengaruh signifikan dan positif terhadap kepuasan masyarakat Kabupaten Sragen yang melakukan pelayanan e-KTP. Hal tersebut didukung dengan hasil uji t (uji parsial)

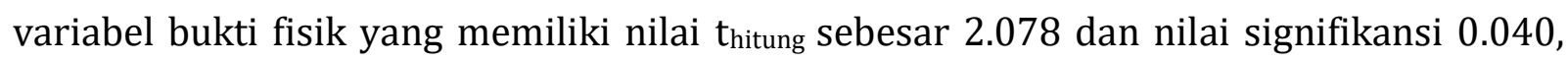
perbandingan nilai $t_{\text {hitung }}$ dengan nilai $t_{\text {tabel, }}$ sehingga ditemukan hasil bahwa nilai $t_{\text {hitung }}$ variabel bukti fisik memiliki nilai 2.078, angka tersebut lebih besar dari nilai $t_{\text {tabel }}$ yaitu 1.986, kemudian untuk perbandingan nilai signifikansi dengan nilai taraf signifikansi, yaitu 0.05, ditemukan hasil bahwa nilai signifikansi variabel bukti fisik sebesar 0.040 lebih kecil dari 0.05 .

\section{Kepuasan Masyarakat Terhadap Kualitas Pelayanan E-KTP}

Variabel bukti fisik mempunyai pengaruh signifikan karena nilai $t_{\text {hitung }}$ lebih besar daripada nilai $t_{\text {tabel }}$ dan nilai signifikansi lebih kecil dari nilai taraf signifikansi, hasil penghitungan tersebut sama dengan penelitian yang dilakukan oleh (Anisa, 2018) dimana variabel bukti fisik berpengaruh signifikan terhadap kepuasan masyarakat. Faktor lain yang mempengaruhi, karena bukti fisik ini merupakan bentuk penampakan fisik atau yang tampak, seperti penampilan pegawai dan fasilitas yang ada, maka masyarakat yang sedang melakukan pelayanan cenderung akan melihat bukti atau fakta yang ada di dalam instansi Dispendukcapil Kabupaten Sragen, fasilitas yang tersedia tentu akan membuat masyarakat menjadi lebih nyaman dalam melakukan pelayanan eKTP, walaupun dalam beberapa pertanyaan juga didapatkan skor yang rendah, seperti misalnya dalam penggunaan jaringan internet di bagian pelayanan e-KTP, banyak dari responden terutama usia $>50$ tahun ke atas yang memberi skor rendah terhadap indikator tersebut. Untuk indikator pertanyaan yang lain skor yang diberikan juga relatif berimbang karena perbandingan skor tinggi dan rendah kurang lebih sama.

Variabel empati juga mempunyai pengaruh signifikan terhadap kepuasan masyarakat, karena nilai thitung lebih besar daripada nilai ttabel dan nilai signifikansi lebih kecil daripada nilai taraf signifikansi, hasil penelitian tersebut sama dengan penelitian 
yang dilakukan (Anisa, 2018) dimana variabel empati berpengaruh signifikan terhadap kepuasan masyarakat, walaupun dalam hasil penghitungan kuisioner cenderung menunjukkan skor yang rendah. Skor rendah tersebut dikarenakan masyarakat masih merasa pegawai Dispendukcapil kurang detail dan tidak memberikan informasi yang jelas ketika sedang ditanya oleh masyarakat yang sedang melakukan pelayanan e-KTP. Karena variabel empati ini mempunyai skor yang rendah tetapi juga berpengaruh signifikan maka seharusnya akan menjadi bahan pertimbangan untuk Dispendukcapil Kabupaten Sragen dalam meningkatkan kualitas pelayanan, terutama pelayanan pegawai terhadap masyarakat yang membutuhkan bantuan dalam pelayanan e-KTP.

Variabel Kehandalan (Reliability), Daya Tanggap (Responsibility), dan Jaminan (Assurance) tidak mempunyai pengaruh signifikan terhadap kepuasan masyarakat Kabupaten Sragen yang pernah atau sedang melakukan pelayanan e-KTP, karena dalam hasil olah data nilai $t_{\text {hitung }}$ ketiga variabel tersebut lebih kecil daripada nilai $t_{\text {tabel }}$ dan nilai signifikansi lebih besar daripada nilai taraf signifikansi. Hasil tersebut sama dengan penelitian yang dilakukan oleh (Sinaga \& Hidayat, 2016) dimana variabel kehandalan, daya tanggap dan jaminan tidak berpengaruh signifikan terhadap kepuasan masyarakat. Berdasarkan hasil olah data penelitian didapatkan pula bahwa variabel jaminan memperoleh nilai SKM tertinggi daripada variabel lain tetapi juga tidak berpengaruh signifikan terhadap kepuasan masyarakat di Kabupaten Sragen, walaupun ketiga variabel tersebut tidak berpengaruh signifikan tetapi indikator pertanyaan harus menjadi dasar untuk membuat pelayanan e-KTP di Dispendukcapil Kabupaten Sragen menjadi lebih baik.

\section{KESIMPULAN}

Hasil analisis regresi linier berganda menunjukkan hanya ada 2 (dua) variabel yang berpengaruh signifikan dan positif terhadap kepuasan masyarakat Kabupaten Sragen yang pernah atau sedang melakukan pelayanan e-KTP, yaitu Bukti Fisik (Tangible) dan Empati (Emphaty), sedangkan untuk variabel Kehandalan (Reliability), Daya Tanggap (Responsibility), dan Jaminan (Assurance) tidak mempunyai pengaruh signifikan terhadap kepuasan masyarakat Kabupaten Sragen yang pernah atau sedang melakukan pelayanan e-KTP. Oleh karena itu saran dalam penelitian ini antara lain, untuk kedepannya objek penelitian bukan hanya tentang e-KTP, tetapi keseluruhan tentang kualitas pelayanan publik yang berada di Dispendukcapil Kabupaten Sragen dan jumlah 
sampel diambil lebih banyak lagi agar generalisasi penelitian lebih kuat serta instrument menjadi lebih lengkap mendalam, sedangkan untuk Dispendukcapil Kabupaten Sragen agar kedepannya memanfaatkan aplikasi yang sedang dirintis yaitu PANDU ONLINE karena dalam masa pandemi Covid-19 ini pelayanan terhadap masyarakat harus tetap berjalan optimal. Selain itu, untuk mencegah penyebaran virus serta membuat pelayanan menjadi lebih cepat sehingga masyarakat, utamanya yang berdomisili jauh dari pusat kota, menjadi lebih terbantu dengan adanya aplikasi tersebut.

\section{REFERENSI}

Anisa, S. (2018). Pengaruh Pelayanan Publik Terhadap Kepuasan Masyarakat di Kantor Desa Helvetia. Jurnal Ekonomi Islam, 1-82.

ANRI. (2012). Arsip Kependudukan, Arsip Terjaga Milik Negara. ARSIP (Media Kearsipan Nasional), 1-62.

Arianto, A. (2019). Disdukcapil Kehabisan Blangko, 5.000 Warga Wonogiri Tak Punya eKTP. Retrieved from news.detik.com: https://news.detik.com/berita-jawatengah/d-4640091/disdukcapil-kehabisan-blangko-5000-warga-wonogiri-takpunya-e-ktp.

Dispermasdukcapil, D. K. (2019). Jumlah Wajib KTP dan Kepemilikan KTP per Kabupaten/Kota. Retrieved from http://data.jatengprov.go.id: http://data.jatengprov.go.id/dataset/data-dukcapil dispermasdesdukcapil/resource/21eea79e-635c-496b-b02f-8a3a9ac80fc1

Febriharini, M. P. (2016). Pelaksanaan Program e-KTP Dalam Rangka Tertib Administrasi Kependudukan . Serat Acitya-Jurnal Ilmiah UNTAG Semarang, 17-30.

Humas Pemkab Sragen . (2019). Tiga Inovasi Dispendukcapil Kabupaten Sragen di Launching Bupati. Retrieved from http://www.sragenkab.go.id: http://www.sragenkab.go.id/berita-1740.html.

Panjaitan, J. E., \& Yuniati, A. L. (2016). Pengaruh Kualitas Pelayanan Terhadap Kepuasan Pelanggan Pada JNE Cabang Bandung. DeReMa Jurnal Manajemen, 265-289.

Sinaga, J. O., \& Hidayat, R. (2016). Jurnal Akuntansi, EkonoPengaruh Kualitas Pelayanan Terhadap Kepuasan Masyarakat Dalam Pelaksanaan Program Pelayanan Administrasi Terpadu Kecamatan (Paten) Di Kecamatan Nongsa Kota Batam. Jurnal Ekonomi dan Bisnis, 7-14.

Sinambela, L. P. (2008). Reformasi Pelayanan Publik. Jakarta: Bumi Aksara.

Sugiyono. (2017). Metode Penelitian Kuantitatif, Kualitatif dan R\&D. Bandung: Alfabeta. 
Sutriadi, E., Dahlan, \& Hasim, D. (2018). Keefektifan Pelayanan Kartu Tanda Penduduk Elektronik Pada Dinas Kependudukan, Catatan Sipil, Tenaga Kerja dan Transmigrasi Kabupaten Soppeng. Jurnal Ilmiah Ilmu Administrasi Publik: Jurnal Pemikiran dan Penelitian Administrasi Publik, 27-36.

Tarmy, A. (2019, Agustus 06). Krisis Blangko e-KTP, 15.401 Warga Sragen Terpaksa Kantongi Suket. Retrieved from news.detik.com: https://news.detik.com/beritajawa-tengah/d-4654492/krisis-blangko-e-ktp-15401-warga-sragen-terpaksakantongi-suke.

Wardoyo, P. (2019). Blangko Kosong, Awas Calo E-KTP dan KK Mulai Gentayangan di Sragen. Ada Yang Patok Rp 100.000 Hingga Rp 3 Juta! Retrieved from joglosemarnews.com: https://joglosemarnews.com/2019/11/blangko-kosongawas-calo-e-ktp-dan-kk-mulai-gentayangan-di-sragen-ada-yang-patok-rp-100-000hingga-rp-3-juta 